Arkadiusz Luboń (D)

Uniwersytet Rzeszowski

arkadiuszlubon@tlen.pl

\title{
Imperatyw konkretyzacji
}

\section{Translatorskie modyfikacje a modele recepcji prozy Howarda Phillipsa Lovecrafta na przykładzie polskich tłumaczeń opowiadania The Outsider}

\section{I}

Napisane w 1921 roku, opublikowane zaś po raz pierwszy pięć lat później (kwiecień 1926) na łamach chicagowskiego periodyku „Weird Tales”, opowiadanie The Outsider stanowi nietuzinkowy tekst w dorobku Howarda Phillipsa Lovecrafta - prozaika, który ,,przez dekady uchodził za trzeciorzędnego autora pretensjonalnego horroru" [Pęczak 2016: 82], obecnie zaś często bywa szufladkowany jako ,potężna globalna marka kultury popularnej, a od pewnego czasu również wysokiej” [Musiał 2015: 70]. Zgodnie z oceną Michela Houellebecqa [2007: 41-42] ten zaledwie kilkustronicowy utwór nie współtworzy serii najważniejszych dzieł pisarza, złożonej z fabuł Zewu Cthulhu, W górach szaleństwa, Koloru z przestworzy, Koszmaru w Dunwich, Szepczacego w ciemności, Snów 
$w$ domu wiedźmy, Widma nad Innsmouth oraz Cienia spoza czasu. Nieprzerwanie jednak stanowi - jak zauważa Sunand Tryambak Joshi [2010: 428] - jedną z jego najczęściej wznawianych opowieści. Od kwietnia 1926 roku, gdy pierwodruk The Outsider wzbudził wśród amerykańskich czytelników „wielką sensację”, należy on do „najbardziej lubianych utworów Lovecrafta" - i to niezależnie od krytycznej autorecenzji samego twórcy ${ }^{1}$, który w liście do Josepha Vernona Shei stwierdzał kategorycznie: „Inni [...] tak samo jak Ty lubią Przybysza, ja jednak - muszę to przyznać - nie podzielam tej opinii" [Joshi 2010: 432].

Na gruncie polskim rozpoznawalność opowiadania The Outsider nie osiągnęła skali zbliżonej do jego poczytności w Stanach Zjednoczonych. Ale choć bez wątpienia nie jest to utwór szczególnie często przedrukowywany przez lokalnych wydawców ${ }^{2}$ twórczości autora $\mathrm{z}$ Providence, to pod jednym przynajmniej względem jego amerykańska popularność jest w rodzimym obiegu literackim wyjątkowo znamiennie reprezentowana mianowicie żaden $\mathrm{z}$ dotychczas opublikowanych w Polsce tekstów Lovecrafta nie doczekał się serii aż pięciu translatorskich interpretacji ${ }^{3}$. A ponieważ publikowano je na przestrzeni ostatnich trzydziestu lat, nie sposób uzasadnić ich powstania i wyraźnej różnorodności ewolucją polszczyzny, a jedynie odmiennymi interpretacjami oryginału. Przed ich scharakteryzowaniem warto najpierw krótko zwrócić uwagę na kluczowe elementy fabuły anglojęzycznego utworu.

\section{II}

Głównym bohaterem i jednocześnie narratorem opowiadania jest osoba wiodąca samotny żywot w miejscu uważanym za starożytny, mroczny zamek: „the castle was infinitely old and infinitely horrible. [...] It was never light, so that I used sometimes to light candles and gaze steadily at

\footnotetext{
1 Jak odnotowuje Finn J. D. John: ,most readers and critics have agreed, over the years, that The Outsider is a fabulous story, one of the very best of Lovecraft's early efforts. In later years the author himself came to disdain it, calling its plotting overly mechanical and its language excessively florid; nearly everyone who has ever read the tale disagrees", cyt. za: H. P. Lovecraft [2018: 225].

2 Więcej na ten temat zob. Jakub Mikulski [2013: 32-43].

3 Autorstwa: Grzegorza Iwanciwa (1989), Roberta Lipskiego (1996), Ewy Morycińskiej-Dzius (2008), Mateusza Kopacza (2011) i Macieja Płazy (2012).
} 
them for relief; nor was there any sun outdoors" [Lovecraft 2018: 226] Jej pochodzenie, wiek i tożsamość nie są określone, a nawet wygląd zewnętrzny pozostaje aż do finalnej partii opowieści tajemnicą - tak dla czytelnika, jak i dla samej postaci. Pozbawiona luster siedziba i całkowita izolacja od jakiejkolwiek społeczności sprawiają, że narrator niewielką wiedzę o sobie i świecie zewnętrznym czerpie jedynie ze szczątkowych wspomnień - „beings must have cared for my needs, yet I cannot recall any person except myself”, „I felt conscious of youth because I remembered so little” - oraz ilustracji z ksiąg wertowanych w blasku świec: „my aspect was a matter equally unthought of, for there were no mirrors in the castle, and I merely regarded myself by instinct as akin to the youthful figures I saw drawn and painted in the books" [ibidem: 226].

Zalążkiem akcji fabularnej w początkowo statycznej i zdominowanej przez fragmenty opisowe narracji jest moment, w którym bohater postanawia poznać świat poza swoją samotnią. Niepomny na niebezpieczeństwa wędrówki w ciemnościach, pnie się w górną część budowli, przedstawionej czytelnikowi jako jedyna na tyle wysoka wieża, by umożliwić obserwację odległej okolicy: „one black tower which reached above the trees into the unknown outer sky" [ibidem: 227]. Szczęśliwe dotarcie do kresu długiej i uciążliwej wspinaczki jest jednocześnie pierwszym punktem zwrotnym w konstrukcji utworu. Ku swojemu zaskoczeniu bohater dostrzega, że zamiast na spodziewany szczyt wieży dotarł w istocie do krawędzi gigantycznej studni w posadzce zapomnianego mauzoleum. Jak określają to interpretatorzy: „nie wspiął się na zawrotną wysokość, lecz po prostu dotarł na twardy grunt" [Joshi 2010: 428]. Oszołomiony odkryciem kontynuuje nocną wyprawę przez cmentarz, pobliskie puszcze i łąki, wiedziony mglistymi nawrotami pamięci lub po prostu instynktem wskazującym mu drogę wprost do rozświetlonego dworu, którego mieszkańcy właśnie biorą udział w hucznym bankiecie: ,an oddly dressed company, indeed; making merry, and speaking brightly to one another" [Lovecraft 2018: 229]. Próba dołączenia do radosnego towarzystwa stanowi jednocześnie drugi punkt zwrotny i kulminacyjny moment w sekwencjach narracji. Przybycie nieoczekiwanego gościa zbiega się w czasie $\mathrm{z}$ wybuchem histerycznego popłochu wśród uczestników rautu. On zresztą reaguje podobnie, gdy po chwili sam dostrzega przyczynę paniki - obecność w sali balowej makabrycznie

$4 \quad$ Cytaty oryginału The Outsider, zgodne z pierwodrukiem z 1926 roku, przytaczane za wydaniem: H. P. Lovecraft [2018]. 
zdeformowanej, lecz niewątpliwie człekokształtnej istoty: „I saw in its eaten-away and bone-revealing outlines a leering, abhorrent travesty on the human shape" [ibidem: 230]. Jej tożsamość ujawnia, po krótkim suspensie fabularnym, ostatnie zdanie opowiadania, pełniące w strukturze utworu funkcję - jak ujęliby to teoretycy formalizmu [por. Szkłowski 1986] - literackiego „,chwytu”, istota okazuje się bowiem lustrzanym odbiciem samego narratora: ,this I have known ever since I stretched out my fingers to the abomination within that great gilded frame; stretched out my fingers and touched a cold and unyielding surface of polished glass" [Lovecraft 2018: 231]. Ponieważ ani życie z ludźmi, ani powrót do odosobnienia nie są możliwe, bohater kończy relację wzmianką o odnalezieniu pobratymców wśród pozostałych istot również ukrywających swoje istnienie przed światem człowieka: „,now I ride with the mocking and friendly ghouls on the night-wind, and play by day amongst the catacombs" [ibidem: 230]. Ustęp ten jest o tyle istotny, że stanowi właściwie jedyny wyraźny łącznik między treścią opowiadania a innymi pracami Lovecrafta, w których pisarz konsekwentnie konstruuje i rozbudowuje uniwersum swojej weird fiction.

Charakter klasycznego, a nawet wtórnego w niektórych rozwiązaniach fabularnych ${ }^{5}$ gotyckiego opowiadania grozy czyni z tekstu Lovecrafta utwór, którego podstawowym przeznaczeniem jest oczywiście poruszenie emocji czytelnika. Zgodnie bowiem ze spostrzeżeniem Noëla Carrolla występujący tu ,potwór jest sprzeczny z naturą, jest metafizycznym odszczepieńcem, wzbudzającym w fikcyjnych bohaterach wstręt, który z kolei ma za zadanie wywołać podobną reakcję u publiczności" [2004: $96]^{6}$. Ale The Outsider to również polemika z tradycyjną realizacją toposu „obcego" i quasi-psychologiczna analiza procesu odkrywania lub konstytuowania tożsamości. W tej opowieści inicjacyjnej, jak stwierdza Ksenia Olkusz, przedmiotem szczególnej uwagi jest „efekt traumy” przeżywanej

\footnotetext{
5 Jak odnotowują krytycy, The Outsider wzorowany jest na wątkach zapożyczonych między innymi z opowiadań Edgara Allana Poego, Oskara Wilde'a, Nathaniela Hawthorne'a czy Mary Shelley [Joshi 2010: 431].

6 Jak stwierdza badacz, niebagatelną rolę w budowaniu nastroju grozy odgrywa w opowiadaniach pisarza niemal strategiczne wytwarzanie w czytelniku ,,poczucia niemożności dokonania opisu”, jakie ,dominuje również w opowiadaniu Obcy (The Outsider) Lovecrafta. Narratorem jest w nim potwór, samotnik w stylu Kaspara Hausera, który nie wie, jak wygląda. Stanąwszy przed lustrem, nie zdaje sobie początkowo sprawy, że widzi własne odbicie”. Lovecraft „opisuje monstra w sposób niejasny, niepełny, co potęguje wrażenie ich amorficzności” [Carroll 2004: 43, 64].
} 
przez bohatera, u którego „,dokonuje się proces samoakceptacji, autoprzypisania do określonego gatunku, stanowiący zarazem akt pogodzenia się Z własną odmiennością" [2008: 190]. Pomimo fragmentów ewidentnie epigońskich opowiadanie - przez samego Lovecrafta określane jako „nieświadome apogeum wśród mych pastiszów Poego" [Joshi 2010: 432] wprowadza do swojego gatunku i dorobku autora istotny detal: jest jednym z przykładów literackiej dekonstrukcji mitologicznych fundamentów zachodniej cywilizacji. W opinii Macieja Płazy „Lovecraft przemyślał, zrozumiał i uwewnętrznił w sobie mit o Minotaurze tak głęboko i twórczo, że przeszedł nawet na drugą stronę labiryntu i spojrzał na człowieka oczyma bestii" - w takim ujęciu omawiany utwór to właśnie niedostrzegany lub marginalizowany przez innych twórców kultury ,rewers okrutnego minojskiego mitu" [2012: 786]. Nie brak wreszcie odczytań tekstu jako świadectwa biograficznych reminiscencji autora $\mathrm{z}$ okresu dzieciństwa ${ }^{7}$, dokumentacyjnego zapisu jego snów ${ }^{8}$ lub po prostu zakamuflowanej manifestacji prywatnego credo pisarza, w której jedna z puentujących fabułę fraz - „I am an outsider; a stranger in this century” [Lovecraft 2018: 231] uważana jest za artystyczną dewizę Lovecrafta.

Ta różnorodność propozycji interpretacyjnych jest oczywiście skutkiem sposobu realizacji głównego wątku opowiadania. Stopniowe odsłanianie tajemnicy tożsamości narratora, dostarczanie czytelnikom kolejnych informacji - niejako wskazówek i poszlak w prowadzonym śledztwie hermeneutycznym - nie kończą się bowiem jednoznacznym rozstrzygnięciem. Nawet opis wyglądu głównego bohatera i wzmianka o jego „nie-ludzkiej” naturze nie przynoszą satysfakcjonującej odpowiedzi na pytanie o to, kim lub czym naprawdę jest. Węzłowy problem fabuły nie zostaje definitywnie

7 „His philosophy of «the outsider, hidden in every human being» may have its roots in his early experiences" [Zwoliński 2009: 165].

8 Więcej na ten temat zob. Sunand Tryambak Joshi [2010: 429-433]. Ponadto odczytanie takie sankcjonują warsztatowe notatki Lovecrafta, o których sam pisarz wzmiankuje, że są to ,pomysły, wizje i cytaty pospiesznie zapisane do ewentualnego wykorzystania w weird fiction [...]. Ich źródła są różne - sny, lektury, losowe zdarzenia, nagie koncepcje i tak dalej”. Zapiski poprzedzające napisanie opowiadania The Outsider, na przykład datowane na rok 1919, to między innymi koncepcje fabularne typu: „strach przed lustrami - wspomnienie snu, w którym scena jest odwrócona, a zakończenie to okropna niespodzianka po ujrzeniu siebie w wodnej tafli lub lustrze (tożsamość?)” lub „gość z grobowca - nieznajomy na publicznym spotkaniu, ktoś go śledzi, gdy o północy wraca na cmentarz, by zejść pod ziemię" [Lovecraft 2013: 99]. 
rozwiązany w obrębie tekstu, a Lovecraft pozostawia wyjaśnienie zagadki domysłom odbiorców.

\section{III}

Większość polskich wersji opowiadania znacząco zawęża spektrum czytelniczych możliwości interpretacyjnych. Obecne w pierwowzorze luki informacyjne i miejsca niedookreślenia [por. Ingarden 2007: 64-72] niwelują translatorskie ingerencje w tekst. Wspólny fundament strategii thumaczy określić można umownym mianem „imperatywu konkretyzacji”, ponieważ przekłady w wyraźny sposób dążą do uzupełnienia niedopowiedzeń oryginału i wskazania możliwie jasnej odpowiedzi na stawiane przez narratora pytania o własną istotę. Co zaś szczególnie ważne, różnice między tymi konkretyzacjami i propozycjami odpowiedzi nie wynikają tylko z odmiennego rozumienia leksykalnej warstwy utworu. Są także skutkiem wpływu na przekłady czynników wprawdzie pozatekstowych, ale oddziałujących na stricte językowe decyzje tłumaczy: zakładanych preferencji odbiorców modelowych, dominujących mód i konwencji literackich, a nawet wizji autora oryginału i samego stanu wiedzy o jego twórczości. Każdy zatem polski wariant, z którym w ostatecznym rozrachunku spotyka się w akcie lektury czytelnik, jest rezultatem nakładania się na artystyczne właściwości pierwowzoru złożonego szeregu elementów kulturowych regulujących proces translacji. Ich liczbę, sposób i zakres oddziaływania na utwór ukazać może analiza porównawcza kolejnych polskich wersji, osadzona jednakże w szerszym kontekście historii recepcji twórczości pisarza. Ogniwa translatorskiej serii ${ }^{9}$, w której obrębie - zgodnie ze spostrzeżeniem Edwarda Balcerzana - ,znaczenia przekładu kształtują się w opozycji (zawsze) do oryginału i (często) do serii" [1968: 40], są bowiem „,doskonałym materiałem do analizy rozmaitych poetyk, języka, bądź języków artystycznych, poszczególnych epok, prądów, twórców, czy też bogactwa interpretacji jednego tekstu artystycznego" [Skwara 2014: 99] ${ }^{10}$.

$9 \quad$ Por. także Edward Balcerzan [1998: 38-40]; Agnieszka Adamowicz-Pośpiech [2013: 19-48].

10 Jak również zauważa Marta Skwara: „komparatystyczna wartość serii przekładowych w kulturze docelowej nie tyle zależy od interpretowalnych (i często spektakularnych) różnic lingwistycznych poszczególnych przekładów, co od innych czynników, zarówno literackich (szczególne znaczenie, oprócz przekształceń poetyki, ma np. intertekstualny wymiar danej serii, czyli to, na ile poszczególne elementy serii 
Pionierskie spolszczenie The Outsider przedstawił Grzegorz Iwanciw w roku 1989 na łamach niskonakładowej (500 egzemplarzy) broszury gdańskiego Informatora Klubu Fantastyki „Collaps”" ${ }^{11}$. Jest to pierwszy w literackim dossier thumacza przekład utworu amerykańskiego prozaika, przygotowany dla numeru periodyku poświęconego tematyce horroru - jak więc obiecuje wielbicielom tego gatunku w słowie wstępnym redaktor naczelny pisma: „straszyć nas będzie nie byle kto, bowiem Howard Phillips Lovecraft jest chyba jedynym pisarzem, który od początku do końca pojął, na czym polega tworzenie literackiego koszmaru" [Kleczyński 1989: strona nienumerowana]. Wariant Roberta Lipskiego, ogłoszony najpierw jako Obcy w 1996 roku, został w późniejszych latach trzykrotnie przedrukowany pod zmienionym tytułem (Przybysz) - za każdym razem jednak w książkowych tomach zbierających najsłynniejsze i najsilniej inspirujące popkulturę utwory Lovecrafta. Przekład Ewy Morycińskiej-Dzius z 2008 roku nie jest translacją amerykańskiego pierwowzoru, lecz hiszpańskiej adaptacji opowiadania, opracowanej trzy lata wcześniej na potrzeby lektury dla dzieci i młodzieży przez Xaviera Vallsa i zamieszczonej w jego El gran libro del miedo. Choć większość różnic między spolszczoną wersją a anglojęzycznym oryginałem jest rezultatem pośrednictwa hiszpańskiego tekstu i ingerencji redaktora tomu w treść opowiadania, to wciąż reprezentuje ona i popularyzuje w świadomości czytelników polskich utwór Lovecrafta - $\mathrm{i}$ już z tego powodu warta jest komparatystycznej refleksji. Czwarty przekład (Obcy) przedstawił w 2011 roku na łamach poświęconego Lovecraftowi serwisu internetowego Mateusz Kopacz ${ }^{12}$, thumacz obszernej biografii pisarza, kolekcji jego listów, esejów i poezji. Wreszcie wydany w 2012 roku Wyrzutek jest najnowszą, rewizyjną wersją opowiadania, przełożoną w celu - jak wzmiankuje Maciej Płaza - ,prostym i zasadniczym:

obecne są w literaturze narodowej), jak i pozaliterackich: wydawniczych, rynkowych, kulturowych czy wreszcie politycznych" [2010: 8-9].

11 Sam tytuł pisma zapisywany też bywa w rejestrach bibliograficznych jako „C(ol) laps" lub „Claps".

12 Wariant ten został przez tłumacza usunięty z zasobów serwisu w grudniu 2018 roku. Swoją decyzję Mateusz Kopacz uzasadnia następująco: „,mój przekład powstał w momencie, gdy na rynku nie było jeszcze bezstronnego pod kątem interpretacyjnym i zadowalającego opracowania The Outsider w języku polskim. W momencie pojawienia się thumaczenia Płazy Obcy w wersji Kopacza nie miał już racji bytowania na stronie. Nieco odwlekałem jego usunięcie, zamierzałem bowiem usunąc cały dział tłumaczeń fanowskich i dokonać nieco zmian w serwisie" (cytat pochodzi z prywatnej korespondencji z thumaczem). 
po raz pierwszy pokazania polskiemu czytelnikowi prawdziwego oblicza prozy Lovecrafta, przetłumaczenia jej tak, jak na to zasługuje" [2012: 788]. Każdy z polskich tłumaczy preferuje inną z możliwych wizji sylwetki pisarza i pierwszoplanowego sensu jego utworu, a w rezultacie wprowadza modyfikacje w różnych jego partiach. Warto też zauważyć, że powstałe w ten sposób warianty czasem dodatkowo uzasadniają i legitymizują elementy poboczne względem samego tekstu - jak choćby towarzyszące mu odredakcyjne objaśnienia, translatorskie komentarze lub grafiki.

\section{IV}

Dedykowane nader precyzyjnie wskazanemu i zawężonemu kręgowi odbiorców - zdeklarowanym fanom powieści grozy - tłumaczenie Iwanciwa subtelnie zmienia wybrane fragmenty oryginału, aby zdeterminować odczytanie opowiadania jako historii „nie-umarłego” arystokraty powstałego po śmierci z własnego grobowca i nawiedzającego rodową siedzibę. Zapowiedź takiego ujednoznacznienia wykładni interpretacyjnej napotyka czytelnik nie tylko na zamieszczonej obok utworu ilustracji (il. 1), ale też w samym tytule. Angielski leksem outsider, definiowany standardowo jako określenie osoby funkcjonującej z niedookreślonych powodów poza (outside - „na zewnątrz”) jakąś grupą, Iwanciw zastępuje terminem ,odszczepieniec” - z reguły zarezerwowanym dla osoby, która ze względów ideologicznych lub religijnych zmuszona jest porzucić swoją dotychczasową społeczność ${ }^{13}$. W samym tekście przekładu nie brak zaś fragmentów przydających bohaterowi cech utożsamianych - podług folklorystyczno-kulturowego stereotypu [por. Petoia 2004] - z naturą wampirów, a więc ,zmarłych odstępców, kacerzy, osób wyklętych, zbrodniarzy, powracających na świat" [Kopaliński 1987: 1247]. Na przykład w opisie przyglądania się narratora swojej podobiźnie z mieszaniną fascynacji i odrazy - „I was almost paralysed, but not too much so to make a feeble effort toward flight; a backward stumble which failed to break the spell in which the nameless, voiceless monster held me" [Lovecraft 2018: 230] - wspomnienie „oczarowania” (spell) zastępuje informacja o zdolności do „hipnotyzowania” wzrokiem: „byłem niemal sparaliżowany, choć stać mnie

\footnotetext{
13 „Outsider - a person who does not belong to a particluar group”, definicja cytowana za słownikiem Merriam-Webster, [online] https://www.merriam-webster.com, 10.01.2019. Znaczenie terminu ,odszczepieniec” definiowane za wykładnią Stownika języka polskiego PWN, [online] https://www. sjp.pwn.pl, 10.01.2019.
} 
było jeszcze na nieśmiałą próbę ucieczki. Cofnąłem się o krok, lecz nie na tyle, by wyzwolić się spod hipnotyzującego spojrzenia bezimiennej postaci" [idem 1989: 5]. Szlachecki rodowód sugeruje nie tylko wizyta w znajomym dworze, ale przede wszystkim oddanie enigmatycznego zwrotu unspeakable quality $\mathrm{z}$ autocharakterystyki „I saw [...] in its mouldy, disintegrating apparel an unspeakable quality that chilled me even more" [idem 2018: 230] - za pomocą bardziej jednoznacznej frazy: „w zbutwiałych szczątkach szat potwora ujrzałem ślady dostojeństwa i bogactwa" [idem 1989: 5]. Wyznanie bohatera, iż niechęć do oglądania

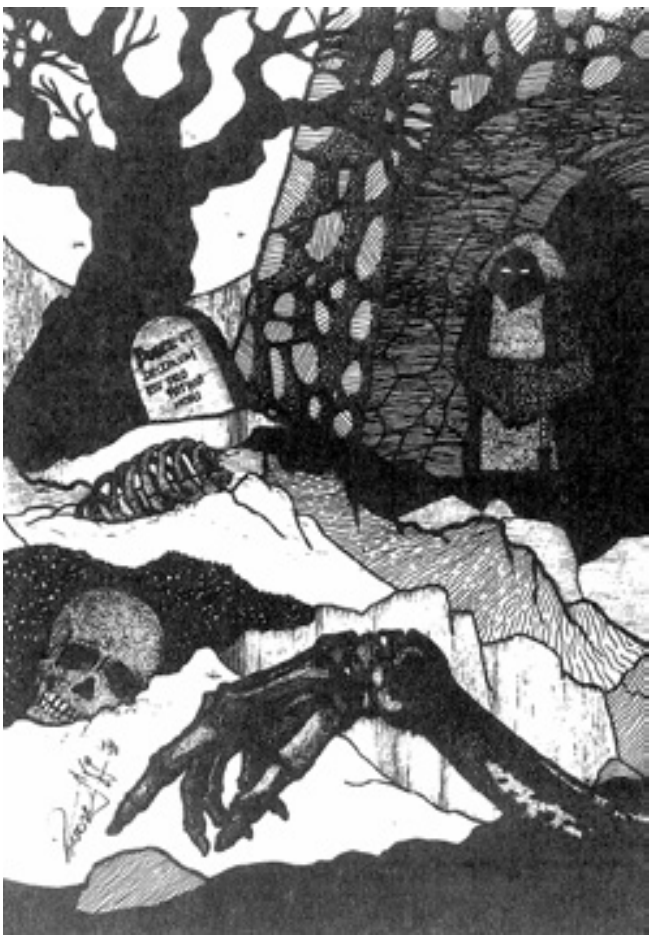

Il. 1. Informator Klubu Fantastyki „Collaps” 29/1989 [nazwisko autora grafiki nieczytelne], s. 3 własnej powierzchowności i konieczność unikania ludzi skłaniają go do ukrywania się pod osłoną nocy - „I know that light is not for me, save that of the moon" [idem 2018: 230] - zyskuje w thumaczeniu formę wyraźnie sugerującą, iż światło słoneczne ma nań szkodliwy wpływ: „wiem, że światło nie służy mi dobrze, z wyjątkiem księżycowej poświaty" [idem 1989: 5]. Ponadto wzmianka o przypuszczalnie młodym wieku lub amnezji niemal pozbawionego wspomnień narratora - „I felt conscious of youth because I remembered so little" [idem 2018: 226] - zostaje w przekładzie pominięta zupełnie. Wreszcie w końcowej scenie odnalezienia przez bohatera podobnych sobie istot zastępuje Iwanciw słowo-klucz mitologii Lovecrafta - ,ghoul” ${ }^{14}$ - polskim

14 W tradycyjnym ujęciu: ,muzułmański zły duch, demon, nieczysty dżinn zamieszkujący ruiny i straszący samotnych podróżnych po drogach. Ghule niekiedy chwytają 
terminem ,wampir”: „teraz wspólnie z wampirami dosiadam nocnego wiatru" [idem 1989: 5].

Czytelnik przekładu adaptacji Xaviera Vallsa z Wielkiej księgi strachu nie znajduje w tekście, niemal czterokrotnie krótszym od anglojęzycznego oryginału, większości tych fragmentów. W wersji przeznaczonej dla dziecięcej publiczności opowieść kończy się wraz ze spojrzeniem bohatera w lustro - brak wzmianki o jego dalszym życiu wśród „nie-ludzkich” współplemieńców nie pozwala odbiorcy identyfikować go inaczej niż jako człowieka. Wszelkie informacje, że początkowym miejscem odosobnienia jest w istocie podziemny kompleks tuneli i komnat, zostają usunięte, na przykład wskutek zastąpienia oryginalnego opisu wyjścia na powierzchnię ziemi - , instead of a dizzying prospect of treetops seen from a lofty eminence, there stretched around me on a level through the grating nothing less than the solid ground" [idem 2018: 228] - ogólnym sformułowaniem: „pchnąłem kratę i wyszedłem na otwartą przestrzeń” [idem 2008: 57]. Wzmiankę o pełnym trumien wnętrzu mauzoleum, do którego wspina się narrator - „I was disappointed; since all that I found were vast shelves of marble, bearing odious oblong boxes of disturbing size" [idem 2018: 227] - reprezentuje w wersji Morycińskiej-Dzius zdawkowy okrzyk zaskoczenia: „Co za rozczarowanie! Nadal skała i czerń” [idem 2008: 57]. $\mathrm{Z}$ kolei obraz nocnego cmentarza, terenu oryginalnie opisanego jako ,decked and diversified by marble slabs and columns, and overshadowed by an ancient stone church, whose ruined spire gleamed spectrally in the moonlight" [idem 2018: 228], zostaje z utworu usunięty. Co więcej, wędrówka zlęknionego bohatera przez ponurą okolicę:

I passed under an arch out of that region of slabs and columns, and wandered through the open country; sometimes following the visible road, but sometimes leaving it curiously to tread across meadows where only occasional ruins bespoke the ancient presence of a forgotten road [ibidem],

zostaje ukazana w formie niemal bukolicznej, oczywiście nieobecnej w pierwowzorze Lovecrafta sceny: ,,szedłem teraz ścieżkami porośniętymi kwieciem, które całowało słońce; spacerowałem tak bez celu, przejęty do głębi widzianymi krajobrazami”" [idem 2008: 57]. Najistotniejszą jednak

ich, by posilić się ich mięsem. A jeśli za dnia nie znajdą wędrowca, którego mogłyby pożreć, udają się nocą na cmentarze, wygrzebują z grobów zwłoki i pożerają je" [Kopaliński 1987: 317]. 
transformacją, jakiej ulega tu anglojęzyczny tekst, jest stopniowe lecz dobitne $\mathrm{i}$ jednoznaczne definiowanie $\mathrm{w}$ toku narracji tożsamości narratora jako dziecka. Gdy na przykład bohater oryginału sięga pamięcią w przeszłość - „beings must have cared for my needs, yet I cannot recall any person except myself" [idem 2018: 226] - to narrator adaptacji wyraźnie postrzega czas miniony w kategoriach wcześniejszych etapów dzieciństwa: „ktoś musiał się mną zajmować, bo byłem wtedy jeszcze małym dzieckiem, ale zupełnie nie pamiętam, kto" [idem 2008: 56]. Wzmiankę o książkowych portretach ludzi - ,the coloured pictures of living beings which I found in many of the mouldy books" [idem 2018: 226] - w tłumaczeniu reprezentuje zdanie: ,jedyne moje wspomnienia innych dzieci i osób dorosłych pochodzą z ilustrowanych książek". Marzenia o kontakcie $\mathrm{z}$ innymi osobami - „I would [...] dream for hours about what I read in the books; and would longingly picture myself amidst gay crowd in the sunny world" [ibidem] - zastępuje fantazja o zabawach w towarzystwie rówieśników: „zwykłem marzyć o śmiechu, zabawie i o słonecznych dniach, jakie spędzały dzieci z czytanych przeze mnie książek" [idem 2008: 56]. Również finalny opis wizyty we dworze i obserwacji zgromadzonych wewnątrz biesiadników - „I looked in and saw an oddly dressed company, indeed; making merry, and speaking brightly to one another" [idem 2018: 229] - wprowadza elementy zgodne z konsekwentnie kształtowanymi przez tekst oczekiwaniami dziecięcego czytelnika: „ujrzałem, że salony są pełne gości - dzieci i dorosłych, pogrążonych w ciekawych rozmowach lub bawiących się w rozmaite gry" [idem 2008: 58]. Oczekiwania te zostają potwierdzone, a interpretacja doprecyzowana i uzupełniona w kulminacyjnej scenie spotkania z własnym odbiciem: narrator okazuje się bowiem zdeformowanym chłopcem, którego jeszcze w dzieciństwie odizolowano od rodziny w śródleśnym więzieniu. Potwierdzenie takiego odczytania znajduje odbiorca nie tylko w towarzyszących tekstowi grafikach (il. 2 i 3), ale przede wszystkim w zastąpieniu informacji o pochodzeniu bohatera - „it was not of this world" [idem 2018: 230] - formułą: było to „stworzenie, które nie miało prawa przyjść na świat”. Fragment ten jest dla opowiadania Lovecrafta na tyle istotny, że warto przywołać wszystkie jego polskie warianty: 


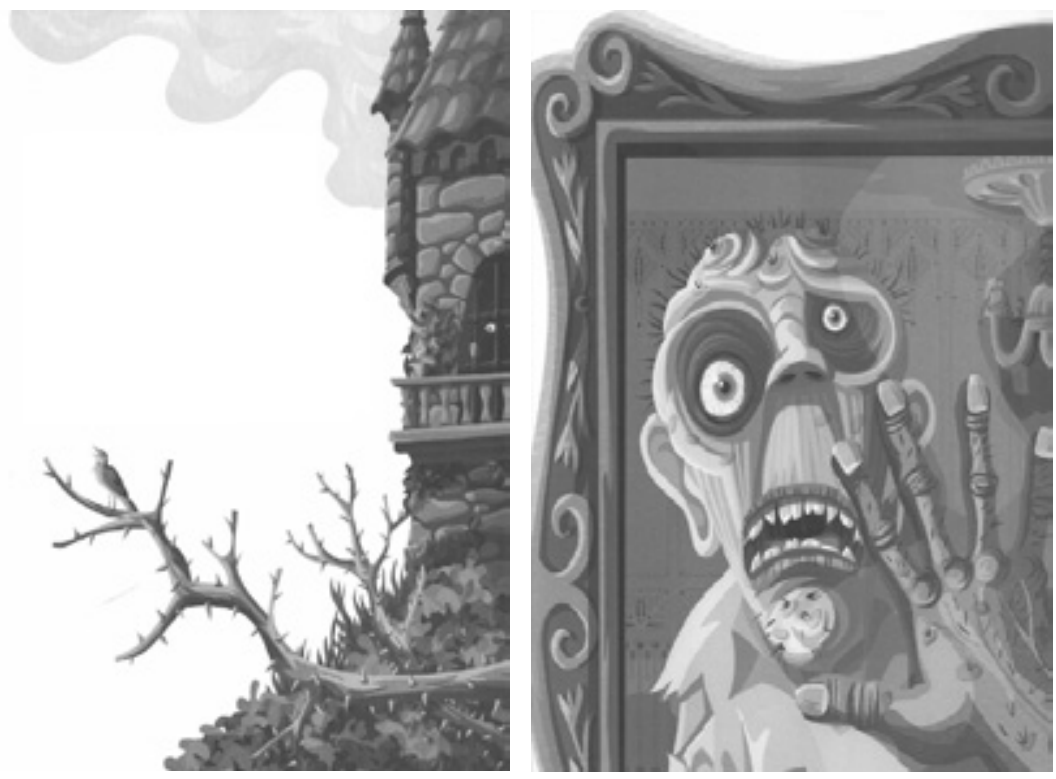

Il. 2 i 3. Wielka księga strachu, il. Pedro Rodriguez, Wydawnictwo Media Rodzina, Poznań 2008, s. 57, 59

\section{Oryginal H. P. Lovecrafta (1926)}

It was $[\ldots]$ the awful baring of that which the merciful earth should always hide. God knows it was not of this world - or no longer of this world - yet to my horror I saw in its eaten-away and bone-revealing outlines a leering, abhorrent travesty on the human shape [Lovecraft 2018: 230].

\section{Przekład R. Lipskiego (1996)}

To coś było [...] ohydnym, okrutnym uzewnętrznieniem tego, co litościwa ziemia powinna na zawsze ukryć w swoich trzewiach. Bóg jeden wie, że nie pochodziło z tego świata - albo przynajmniej

\section{Przekład G. Iwanciwa (1989)}

Było to [...] potworne obnażenie tego, co litościwa ziemia powinna na zawsze pozostawić w ukryciu. Chyba tylko Bóg wie, że postać ta nie należała do tego świata - lub raczej już nie należała. $\mathrm{Ku}$ swemu przerażeniu dostrzegłem w jej poszarpanym, z odsłoniętymi kośćmi ciele odrażającą parodię kształtu ludzkiego [idem 1989: 5].

\section{Przekład E. Morycińskiej-Dzius (2008)}

Z jego lepkich członków sterczały odarte ze skóry kości; okryty był szmatami, które sugerowały, że jest to mimo wszystko ludzka postać. Była to jednak bezkształtna i pozbawiona proporcji 
już nie z TEGO świata - aczkolwiek ku swemu przerażeniu ujrzałem $\mathrm{w}$ jego wyżartym, ziejącym nagimi kośćmi kształcie przeraźliwie ironiczną, zdeformowaną w niemożliwy do wyrażenia sposób trawestację ludzkiej sylwetki [idem 1996: 57].

\section{Przekład M. Kopacza (2011)}

To [...] straszliwe ujawnienie tego, co litościwa ziemia winna po wieki skrywać. Niebiosa wiedzą, że to coś było nie $\mathrm{z}$ tego świata - czy może już nie $\mathrm{z}$ tego świata - aczkolwiek ku mej zgrozie zobaczyłem w jego przeżartych przez czerwie i ukazujących kości kształtach złośliwą, chorą parodię ludzkiej sylwetki [idem 2011: 4]. masa, przyprawiający o mdłości obraz stworzenia, które nie miało prawa przyjść na świat [idem 2008: 58].

\section{Przekład M. Plazy (2012)}

Był to [...] uchylony rąbek wszetecznych sekretów, które miłosierna ziemia winna trzymać w ukryciu. Bóg mi świadkiem, że nie była to istota $\mathrm{z}$ tego świata - bądź już nie z tego świata lecz o zgrozo, w jej kościanych, zgniło rozścierwionych kształtach widziałem przebrzydłą, szyderczą parodię ciała ludzkiego [idem 2012: 36].

Tam, gdzie Iwanciw podkreśla, że życie doczesne narratora w ludzkim świecie i postaci to zamknięty epizod z jego przeszłości („,nie należał do tego świata - lub raczej już nie należał"), zaś wariant Morycińskiej-Dzius skupia się na opisaniu społecznego postrzegania faktu narodzin zniekształconego noworodka (,nie miał prawa przyjść na świat”), przekład Lipskiego eksponuje - także edytorsko, fontem z wersalikami - co innego: równoległe istnienie różnych porządków rzeczywistości, których granicę bohater przekroczy $1^{15}$ (,nie pochodził z tego świata - albo przynajmniej już nie z TEGO świata"). Ale nie tylko wyborem tytułu - Obcy lub Przybysz Lipski wskazuje czytelnikowi, że rodzimy świat outsidera nie jest domeną człowieka. Przede wszystkim tłumacz akcentuje, nierzadko pomijane przez innych przekładowców, a często stosowane przez Lovecrafta słowa-klucze odnoszące się do lokalizacji przestrzennej. $Z$ reguły są one oparte na opozycji wnętrze-zewnętrze: inner-outer, a zwłaszcza beyond - leksem w samym opowiadaniu użyty pięciokrotnie, wykorzystywany przez pisarza ze szczególnym upodobaniem w tytułach innych utworów (From Beyond, Beyond the Wall of Sleep, The Challenge from Beyond). Za przykład niech

\footnotetext{
15 Ten fragment w późniejszych wznowieniach przekładu Lipski zmodyfikował w symboliczny sposób - poprzez zapisanie słowa „tego" zgodnie z anglojęzycznym oryginałem, bez użycia wersalików [Lovecraft 1999: 135].
} 
posłuży najpierw krótki opis wieży-studni pełniącej funkcję „przejścia” między światami:

\section{Oryginal H. P. Lovecrafta (1926)}

There was one black tower which reached above the trees into the unknown outer sky, but that was partly ruined and could not be ascended save by a well-nigh impossible climb up the sheer wall, stone by stone [Lovecraft 2018: 227].

\section{Przekład R. Lipskiego (1996)}

Była co prawda jeszcze jedna wieża, wyrastająca ponad drzewa w nieznane, zewnętrzne niebo, ale częściowo zrujnowana, stała się całkiem niedostępna, jeżeli nie liczyć prawie niemożliwej wspinaczki po pionowym murze, od jednego kamienia do drugiego [idem 1996: 51].

\section{Przeklad M. Kopacza (2011)}

Istniała pewna czarna wieżyca sięgająca ponad wierzchołki lasu w nieznane niebiosa, lecz znajdowała się ona w częściowej ruinie, przez co jedyną możliwością wdrapania się na jej szczyt była niemalże samobójcza wspinaczka po gołej ścianie, kamień po kamieniu [idem 2011: 1].

\section{Przekład G. Iwanciwa (1989)}

Była tam wprawdzie jedna czarna baszta, która sięgała wysoko ponad korony drzew w kierunku nieznanego mi nieba, lecz była na poły ruiną i niepodobna było wspiąć się na nią w inny sposób, jak czepiając się wąskich szczelin między kamieniami muru [idem 1989: 1].

\section{Przekład E. Morycińskiej-Dzius} (2008)

Jedynie wieża z czarnego kamienia, niemal w ruinie, wznosiła się ponad mroki lasu [idem 2008: 56].

\section{Przekład M. Plazy (2012)}

Jedna tylko czarna wieżyca wzbijała się ponad ów gąszcz straszliwy, w nieznane, niedosiężne niebo - była wszakże częściowo zrujnowana, tedy aby dotrzeć na jej szczyt, trzeba by dokonać sztuki omal niemożliwej: kamień po kamieniu wspiąć się po nagim murze [idem 2012: 30-31].

Drugi, nie mniej charakterystyczny przykład, znaleźć można w wyznaniu bohatera, że paradoksalnie to smutne reminiscencje samotnego życia w izolacji przynoszą wytchnienie od nawracającego i nieodpartego wspomnienia traumatycznego spotkania $\mathrm{z}$ własnym odbiciem: 


\section{Oryginal H. P. Lovecrafta (1926)}

And yet I am strangely content, and cling desperately to those sere memories, when my mind momentarily threatens to reach beyond to the other [idem 2018: 226].

\section{Przekład R. Lipskiego (1996)}

A jednak jestem dziwnie kontent, i częstokroć wracam rozpaczliwie do tych wspomnień, kiedy mój umysł choćby tylko chwilowo groził sięgnięciem poza pewną granicę, hen, tam, dalej [idem 1996: 49].

\section{Przekład M. Kopacza (2011)}

A mimo to jestem dziwnie rad i trwam przy owych uwiędłych wspomnieniach w chwilach, gdy umysł mój zagraża próbą zapuszczania się daleko $\mathrm{w}$ inne rejony [idem 2011: 1].

\section{Przekład G. Iwanciwa (1989)}

Lecz jestem dziwnie zadowolony z takiego stanu rzeczy i rozpaczliwie trzymam się tych marnych wspomnień w chwilach, gdy mój umysł zagraża mi, że sięgnie do „tego drugiego" [idem 1989: 1].

\section{Przekład E. Morycińskiej-Dzius (2008)}

[fragment nieobecny w wersji polskiej]

\section{Przeklad M. Plazy (2012)}

A przecież jednak ze zwiędłych tych wspomnień czerpię dziwną radość, hołubię je w sobie z trwożną rozpaczą ilekroć myśl moja, omsknąwszy się, sięgnie do tego, co zdarzyło się potem [idem 2012: 30].

Dwuwymiarowa architektura świata przedstawionego jest w przekładzie Lipskiego konsekwentnie zachowywana. Obecność granicy rozdzielającej konstrukcję schematu wyobrażeniowego rzeczywistości - dodatkowo podkreślona. Jeżeli zauważymy również, że tłumaczenie rezygnuje z poszukiwania zastępników dla słowa określającego w finale opowiadania rasę stworzeń pokrewnych głównemu bohaterowi (,ghoul”) - „teraz mknę z drwiącymi i przyjaznymi ghulami pośród nocnego wiatru" [idem 1996: 59] - to wyraźna staje się różnica między wariantem Lipskiego a wersjami wcześniejszymi. Jej narratorem jest przybyła z bliżej nieokreślonego ,zewnętrza”, nieznanego ,innego wymiaru” istota (il. 4), którą po długim okresie ukrywania się w prastarym podziemiu zrządzenie losu konfrontuje z ludzkością zamieszkującą powierzchnię planety. W analogiczny sposób ukazani są przedstawiciele tegoż gatunku w pozostałych fabułach Lovecrafta. Ghule występują bowiem także w Modelu Pickmana czy $W$ poszukiwaniu nieznanego Kadath, a więc w spolszczeniach utworów Pickman's Model i The Dream-Quest of 


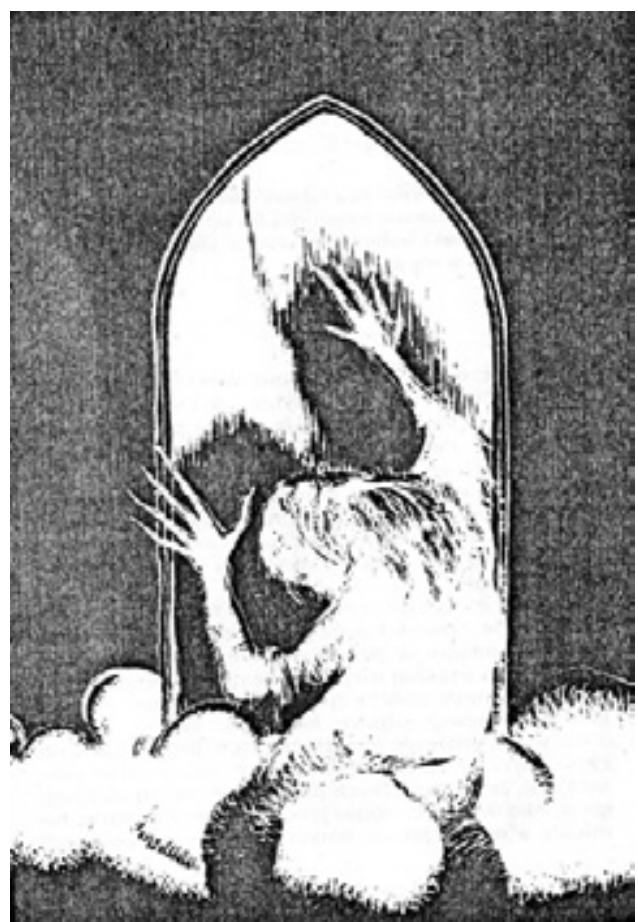

Il. 4. W poszukiwaniu nieznanego Kadath, il. Hubert Czajkowski, Wydawnictwo S. R., Warszawa 1996, s. 50

Unknown Kadath, zgromadzonych wraz z przekładem The Outsider na łamach tomów publikowanych w Polsce $^{16}$. Rozwiązania translatorskie Lipskiego mają zatem dodatkowe uzasadnienie w powstałych wcześniej lub w podobnym okresie przekładach innych dzieł autora, a w konsekwencji też dodatkowy wpływ na dalszą recepcję jego prozy. Przyczyniają się do wzmocnienia spójności uniwersum tworzonego przez pisarza, pozwalają podkreślić konsekwencję kreślonej przezeń wizji fantastycznego świata oraz oryginalność przetworzeń motywów zaczerpniętych z kanonu literatury, folkloru i historii różnych kultur.

Ta strategia translatorska organizuje również późniejszy przekład Mateusza Kopacza - ogłoszony już w dekadzie, w której ostatnie nieprzetłumaczone dotychczas utwory Lovecrafta opublikowano w polskich wersjach ${ }^{17}$. Z tą jednak różnicą, że Kopacz klarowniej niż Lipski ${ }^{18}$ identyfikuje miejsce pochodzenia narratora

\footnotetext{
16 W poszukiwaniu nieznanego Kadath (tłum. Robert Lipski i Anna Ledwożyw) z 1996 roku oraz $W$ górach szaleństwa i inne opowieści (tłum. Robert Lipski et al.) z 2017.

17 Wydany w marcu 2018 roku tom Wyzwanie z innego świata (thum. Radosław Jarosiński i Mateusz Kopacz) zgromadził ostatnie niedostępne dotąd w wersjach polskich utwory prozatorskie Lovecrafta.

18 Warto odnotować, że własne thumaczenie The Outsider poprzedził Kopacz analizą propozycji Lipskiego, o którego wariancie pisze: ,autor przekładu [...] w edycjach
} 
jako przestrzeń zlokalizowaną w głębi Ziemi - zgodnie zresztą ze spostrzeżeniem Daniela Misterka [1998: 122] o ważkiej roli, jaką w utworach Lovecrafta pełni sekretny „podziemny świat”, czy opinią Anny Krawczyk-Łaskarzewskiej, że celem nadrzędnym twórczości autora jest „oddanie grozy życia obok «obcych», istot lub bóstw, które pochowały się gdzieś w czeluściach naszej planety, $[\ldots]$ a o ich istnieniu przekonują się na własne oczy tylko nieliczni z protagonistów" [2009: 41-42 $]^{19}$. Nawiązania opowieści o obcym przybyszu z podziemnych sfer do całokształtu literackiej twórczości amerykańskiego pisarza wzmocnione są w wersji Kopacza, po pierwsze, dzięki wprowadzeniu przypisów translatorskich. Za pomocą paratekstów tłumacz nie tylko objaśnia, ale także segreguje elementy fabuły przynależne wyłącznie autorskiej fikcji od tych przeszczepionych z pozatekstowych realiów. Za reprezentacyjny przykład niech posłuży poniższy fragment monologu:

\section{Oryginal H. P. Lovecrafta (1926)}

Now I ride with the mocking and friendly ghouls on the night-wind, and play by day amongst the catacombs of Nephren-Ka in the sealed and unknown valley

\section{Przekład G. Iwanciwa (1989)}

Teraz wspólnie z wampirami i dosiadam nocnego wiatru, a za dnia bawię się w katakumbach Nefren-Ka w nieznanej dolinie Hadoth nad Nilem. Wiem, że

wydawnictwa Zysk zmienił tytuł tego tekstu na Przybysz. Czemu? W takiej postaci tytuł wyraźnie mówi, że główny bohater tekstu skądś przybył. Tymczasem pod koniec tekstu czytamy: «pozostanę już przybyszem z zewnątrz - obcym w tym stuleciu»; dlaczego «przybysz z zewnątrz», skoro główny bohater pochodzi raczej z «wewnątrz» - z podziemi? Czyżby Lipski sugerował, że narrator jest przybyszem z obcej planety czy wymiaru (bowiem w takim znaczeniu Lovecraft najczęściej posługiwał się słowem «zewnętrze»)? W oryginale stoi wyraźnie: «I know always that I am an outsider; a stranger in this century» - nie ma żadnego podkreślenia faktu, że narrator jest «outsiderem» właśnie z zewnątrz. Może przypisuję temu zbyt wielką wagę, ale w wyniku takiego a nie innego przekładu ja sam byłem przekonany, że postać z tego opowiadania pochodzi z przestrzeni kosmicznej. A nie to miał na myśli autor dzieła" [Kopacz 2010: 26].

19 Jak ujmuje to Stanisław Lem w swojej krytycznej opinii na temat opowiadań amerykańskiego pisarza: ,świat Lovecrafta to w oczach topniejąca malutka wysepka normalności, podminowana otchłannymi siedzibami jakichś monstrów bądź demonów" [1976: 233]. 
of Hadoth by the Nile. I know that light is not for me, save that of the moon over the rock tombs of $\mathrm{Neb}$, nor any gaiety save the unnamed feasts of Nitokris beneath the Great Pyramid [Lovecraft 2018: 230-231].

\section{Przeklad R. Lipskiego (1996)}

Teraz mknę z drwiącymi i przyjaznymi ghulami pośród nocnego wiatru, a za dnia igram wśród katakumb Nephren-Ka w niedostępnej, nieznanej kotlinie Hadoth nad Nilem. Wiem, że światło dnia nie jest dla mnie odpowiednie, jedynie blask księżyca skąpujący kamienne grobowce Neb, podobnie jak radość i swawola, za wyjątkiem tajemnych uczt Nitokris w podziemiach Wielkiej Piramidy [idem 1996: 49].

\section{Przekład M. Kopacza (2011)}

Dziś ujeżdżam z drwiącymi i zaprzyjaźnionymi gulami nocny wicher, a za dnia igram pośród katakumb Nephrena-Ka w zapieczętowanej i nieznanej dolinie Hadoth nad Nilem. Wiem, że światło nie jest mi przeznaczone, chyba że blask księżyca nad skalnymi grobowcami $\mathrm{Neb}^{*}$, ani też radość inna niż ta panująca na nienazwanych ucztach Nitokris pod Wielką Piramidą**.

* Nephren-Ka, Hadoth i Neb to elementy fikcyjne (przyp. thum.).

** Nitokris to z kolei prawdziwa postać. Była królową Egiptu ok. XXI w. p.n.e. Słynie $\mathrm{z}$ historii zatopienia swoich wrogów podczas uczty w świątyni pod Nilem (przyp. tłum.) [idem 2011: 4-5]. światło nie służy mi dobrze, $\mathrm{z}$ wyjątkiem księżycowej poświaty nad kamiennymi grobowcami Neb. Nie znam też innej radości prócz tej, która panuje na ucztach u Niktoris, w głębi Wielkiej Piramidy [idem 1989: 5].

\section{Przekład E. Morycińskiej-Dzius (2008)}

[fragment nieobecny w wersji polskiej]

\section{Przeklad M. Plazy (2012)}

Przyjęła mię kompania przyjaznych, kpiarskich strzyg - razem cwałujemy na skrzydłach nocnego wiatru, a za dnia igramy śród katakumb Nephrena-Ka, w strzeżonej, nieznanej dolinie Hadoth nad Nilem. Wiem już, ze nie zaznam światła innego niż to, którym księżyc oblewa skalne grobowce w Neb, ani innego wesela niż nieopisane uczty królowej Nitokris popod Wielką Piramidą [idem 2012: 37]. 
Po drugie, syntezujący stosunek do twórczości Lovecrafta pozwala tłumaczowi na drobne, acz symptomatyczne korekty detali tekstu, czego w przywołanym ustępie dobrym przykładem jest forma gramatyczna nazwy własnej „Nephren-Ka”. We wcześniejszych przekładach funkcjonuje ona jako toponim, w Obcym Kopacza jest - zgodnie z zastosowaniami w innych utworach pisarza - bez wątpienia antroponimem, imieniem fikcyjnej postaci płci męskiej. To językowy niuans, jednak jego rozstrzygnięcie wymaga od tłumacza albo znajomości pozostałych prac autora oryginału, albo wglądu w kompleksowe ustalenia interpretatorów i encyklopedie Lovecraftowskiej mitologii - w dużej mierze niedostępne do późnych lat 90. XX wieku.

Chronologicznie ostatni wariant opowiadania w historii polskiej serii przekładowej The Outsider stanowi propozycję pozwalającą odbiorcom na największą swobodę interpretacyjną. Zarazem jest też najwyraźniejszym przykładem przezwyciężenia przez tłumacza ,imperatywu konkretyzacji”, translatorskiej. W Wyrzutku Macieja Płazy tajemnica tożsamości narratora nie jest bowiem, podobnie jak w oryginale, jednoznacznie rozstrzygnięta. Czytelnicy kończą lekturę jedynie z wiedzą, że jest on istotą odrzuconą przez ludzką społeczność, a jego przygoda to „wytwór obłędu, przyśnienia czy mocy czarodziejskich" [Lovecraft 2012: 34]. Tym jednakże, co dodatkowo wyróżnia wersję Płazy, jest metodycznie stosowana przez tłumacza archaizowana leksyka i składnia. Zdania typu: „zamek ów niechybnie był moim mieszkaniem, lecz jak wiele trwało to lat - nie pomnę”, ,cienie jęły gęstnieć, a powietrze wypełniło się posępną trwogą - rzuciłem się przeto jak szaleniec z powrotem” tudzież „w którąkolwiek jednak stronę się zwróciłem, tam spotykało mię rozczarowanie: wszędy znajdowałem jeno masywne marmurowe półki” [ibidem: 31-32] - oczywiście służą podkreśleniu obcości bohatera i symbolicznie zwiększają dystans między nim a napotkanymi ludźmi. Niemniej takiego stopnia archaizacji nie uzasadnia wyłącznie kształt językowy oryginału ${ }^{20}$, z nielicznymi bezspornie przestarzałymi wtrętami. Translatorską licentia poetica motywuje w tym przypadku kolejny czynnik, pozajęzykowy i pozatekstowy wobec utworu wizja sylwetki artystycznej pisarza, którą Płaza charakteryzuje słowami:

20 Odpowiadające tym zdaniom fragmenty oryginału brzmią odpowiednio: „I must have lived years in this place, but I cannot measure the time”, ,the shade grew denser and the air more filled with brooding fear; so that I ran frantically back” oraz „,but on every hand I was disappointed; since all that I found were vast shelves of marble" [Lovecraft 1926]. 
„duchem Lovecraft tkwił właściwie w XVIII stuleciu, w idealizowanym przez siebie wieku oświecenia" i ,jako stylista był mocno staroświecki”. Dlatego też jego prozy „nie należy przekładać stylem mu współczesnym”:

[...] szukałem inspiracji głównie w literaturze młodopolskiej i romantycznej; wydało mi się wskazane, by styl polskich przekładów Lovecrafta był staroświecki, i to tak, jak staroświecki byłby dla dzisiejszego czytelnika styl pisarza niemodnego już wówczas, osiemdziesiąt lat temu [Płaza 2012: 770, 790-791].

Decyzję tłumacza uprawomocniają dostępne od końca ostatniej dekady ubiegłego wieku diagnozy literaturoznawców oraz opracowania biograficz$\mathrm{ne}^{21} \mathrm{i}$ bibliograficzne, wśród nich przede wszystkim archiwum korespondencji pisarza z autorską oceną The Outsider: ,napuszoność i bombastyczność języka jest tu już zupełnie komiczna. Czytając dziś po raz kolejny ten utwór, ciężko mi pojąć, jak mogłem zaplątać się w tak barokową, czczą retorykę" [Joshi 2010: 432].

V

Zapewne nie sposób przedstawić kompletnej listy czynników mających wydatny wpływ na to, że jedno anglojęzyczne opowiadanie reprezentuje na gruncie kultury polskiej kilka de facto różnych utworów. Bez wątpienia jednak istotna część determinant pracy translatorskiej ma charakter w dużej mierze niezależny od samej interpretacji litery oryginału. To wszak wzgląd na preferencje fanów opowieści grozy oraz stereotypowa wizja Lovecrafta jako kopisty schematów tego gatunku sprawiają, że Grzegorz Iwanciw proponuje czytelnikom skonwencjonalizowaną historię o powstałym z grobu wampirze. Odwrotnie jest w późniejszych wariantach Mateusza Kopacza i Roberta Lipskiego - to właśnie postrzeganie autora w kategoriach innowacyjnego reformatora zastanych modeli literackich, twórcy skomplikowanego i wielowymiarowego fantastycznego uniwersum, skutkuje wprowadzeniem do polskiego obiegu literackiego fabuły o kontakcie z ludzkością istoty rodem z sekretnych, ukrytych przed świadomością człowieka głębin Ziemi (wersja Kopacza) lub rubieży kosmosu czy zakątków równoległego wszechświata (wersja Lipskiego). Dostosowanie tekstu do specyfiki recepcji, oczekiwań i kompetencji lekturowych młodszych czytelników powoduje, że skrócony, pseudobaśniowy wariant

21 Pierwszą obszerną i rzetelnie udokumentowaną biografię Lovecrafta wydał w 1996 roku Joshi. Jej polski przekład ukazał się w roku 2010. 
Ewy Morycińskiej-Dzius - za pośrednictwem hiszpańskiej adaptacji proponuje odbiorcom opowieść o dramacie odtrąconego z powodu swej fizycznej odmienności dziecka. Przekład Macieja Płazy w największym stopniu unika ujednoznaczniających treść rozwiązań leksykalnych, aby tym sugestywniej przedstawić konfrontację ludzkości z niezrozumiałą, niedefiniowalną w sztampowych kategoriach obcością oraz oddać w polszczyźnie dostrzeżony u Lovecrafta literacki, lecz przede wszystkim intelektualny eksperyment:

[...] posłuchajmy [...] co miałby nam do powiedzenia negatywny bohater naszej pysznej i fałszywej kultury; spytajmy go, jak czuł się w swej samotni będącej przedłużeniem i pomnikiem jego potworności; spójrzmy w lustro oczyma kogoś, kto jest wstrętny, nikczemny i bluźnierczy zarazem; poczujmy na własnej skórze nieodwołalność tego wyroku, stańmy się choć na chwilę wcieloną innością, negatywnością, zaprzeczeniem. Wzdrygnijmy się z odrazy i westchnijmy jak obudzeni z koszmarnego snu, z ulgą, że jesteśmy normalni, dobrzy i piękni, że jesteśmy tam gdzie trzeba, po stronie większości [Płaza 2012: 786].

„Oczyma kogoś” - ale kogo? Nawet skrupulatna i kunsztowna analiza translatorska rzadko stanowi konkurencyjnie atrakcyjną alternatywę dla wyrazistych i plastycznych obrazów tak absorbujących wyobraźnię lekturową. Osobliwie to więc ten właśnie wariant, najbliższy filozofii artystycznego projektu Lovecrafta i przez to w szczególny sposób „wierny oryginałowi”, okazuje się najmniej typowym ogniwem przekładowego cyklu. Opór wobec ,imperatywu konkretyzacji” pozwala Płazie pozostawić fabularną enigmę nadal nierozwikłaną, beletrystyczną łamigłówkę bez rozszyfrowania w obrębie opowieści narratora, a egzegetyczny dylemat wciąż do dyspozycji czytelników. Niemniej przypadki spolszczeń The Outsider dobitnie pokazują, jak interesujące dla thumacza jest trudno uchwytne przejście od misji międzyjęzykowego pośrednika i filologicznego hermeneuty do roli wytrawnego literackiego szaradzisty, który znalazł - i z satysfakcją prezentuje odbiorcom w treści translacji - unikalny sposób eksplikacji zagadkowego, a wciąż nieprzeciętnie popularnego tekstu kultury.

Jeśli zatem tak uwarunkowaną interpretacyjną praktykę thumaczy prozy Lovecrafta postrzegać jako pasmo twórczych eksperymentów o ciekawych i różnorodnych rezultatach, to - biorąc pod uwagę utrzymującą się dziś na wysokim poziomie poczytność dzieł amerykańskiego pisarza - należy jedynie cierpliwie oczekiwać na dalsze mutacje i transformacje jego wciąż 
na nowo odkrywanych utworów. Wraz z nimi zaś na kolejne propozycje wyjaśnienia tajemnicy Outsidera, którą autor z Providence ciągle intryguje rosnące grono swoich polskich czytelników - w ich liczbie także tych najdociekliwszych: przekładowców.

\section{Bibliografia}

\section{Wersje opowiadania The Outsider w kolejności ukazywania się}

Lovecraft, H. P. (1926), „The Outsider”, [w:] H. P. Lovecraft (2018), The Complete Fiction Omnibus. The Early Years 1908-1925 (oprac. Finn J. D. John), Pulp-Lit Productions, Corvallis, 225-231.

Lovecraft, H. P. (1989), „Odszczepieniec” (thum. Grzegorz Iwanciw), Collaps. 29: 1-5.

Lovecraft, H. P. (1996), „Obcy”, [w:] H. P. Lovecraft, W poszukiwaniu nieznanego Kadath (tłum. Robert Lipski i Anna Ledwożyw), Wydawnictwo S. R., Warszawa, 49-59.

Lovecraft, H. P. (1999), „Przybysz”, [w:] H. P. Lovecraft, Coś na progu (thum. Robert Lipski), Wydawnictwo Zysk i S-ka, Poznań, 129-137.

Lovecraft, H. P. (2008), „Obcy”, [w:] Xavier Valls, red. Wielka księga strachu (thum. Ewa Morycińska-Dzius), Wydawnictwo Media Rodzina, Poznań, 56-59. Lovecraft, H. P. (2011), „Obcy” (thum. Mateusz Kopacz), H. P. Lovecraft. Polski serwis, [online] http://www.hplovecraft.pl, 20.06.2018.

Lovecraft, H. P. (2012), „Wyrzutek”, [w:] H. P. Lovecraft, Zgroza w Dunwich $i$ inne przerażajace opowieści (tłum. Maciej Płaza), Wydawnictwo Vesper, Poznań, 29-37.

\section{Literatura przedmiotu}

Adamowicz-Pośpiech, A. (2013), Seria w przektadzie. Polskie warianty prozy Josepha Conrada, Wydawnictwo Uniwersytetu Śląskiego, Katowice.

Aleksandrowicz-Pędich, L. (red.) (2009), $W$ kanonie prozy amerykańskiej, t. 2: Z placu Waszyngtona do Domu z liści, Wydawnictwo SWPS Academica, Warszawa.

Balcerzan, E. (1998), Literatura z literatury (strategie tlumaczy), Wydawnictwo Naukowe „Śląsk”, Katowice.

Balcerzan, E. (1968), „Tłumaczenie poetyckie wśród kontekstów historycznoliterackich”, [w:] Maria Renata Mayenowa, Janusz Sławiński, red. Prace z poetyki poświęcone VI Międzynarodowemu Kongresowi Slawistów, Zakład Narodowy im. Ossolińskich, Wrocław, 32-59. 
Burzyńska, A., Markowski, M. P. (red.) (2007), Teorie literatury XX wieku. Antologia, SIW Znak, Kraków.

Carroll, N. (2004), Filozofia horroru albo Paradoksy uczuć (thum. Mirosław Przylipiak), Słowo/obraz terytoria, Gdańsk.

Houellebecq, M. (2007), H. P. Lovecraft - Przeciw światu, przeciw życiu (tłum. Jacek Giszczak), Wydawnictwo W.A.B., Warszawa.

Ingarden, R. (2007), „Z teorii dzieła literackiego”, [w:] Anna Burzyńska, Michał Paweł Markowski, red. Teorie literatury XX wieku. Antologia, SIW Znak, Kraków, 43-72.

James, M. R. (1976), Opowieści starego antykwariusza (thum. Janina Mroczkowska), Wydawnictwo Literackie, Kraków.

Joshi, S. T. (2010), H. P. Lovecraft. Biografia (tłum. Mateusz Kopacz), Wydawnictwo Zysk i S-ka, Poznań.

Kleczyński, R. (1989), „Wstęp”, Collaps. 29: strona nienumerowana.

Kopacz, M. (2010), „«Odrażający, bluźnierczy Necronomicon», czyli o polskich przekładach Lovecrafta", Czas Fantastyki. 2(23): 25-29.

Kopaliński, W. (red.) (1987), Stownik mitów i tradycji kultury, Państwowy Instytut Wydawniczy, Warszawa.

Krawczyk-Łaskarzewska, A. (2009), „Pomiędzy wiedzą a grozą - Hawthorne, Gilman, Bierce, Lovecraft", [w:] Lucyna Aleksandrowicz-Pędich, red. W kanonie prozy amerykańskiej, t. 2: Z placu Waszyngtona do Domu z liści, Wydawnictwo SWPS Academica, Warszawa, 30-46.

Lem, S. (1976), „Posłowie”, [w:] M. R. James, Opowieści starego antykwariusza (thum. Janina Mroczkowska), Wydawnictwo Literackie, Kraków, 231-233.

Lovecraft, H. P. (2013), Koszmary i fantazje. Listy i eseje (thum. Mateusz Kopacz), Wydawnictwo Sine Qua Non, Kraków.

Lovecraft, H. P. (2017), W górach szaleństwa i inne opowieści (tłum. Robert Lipski, Ryszard Grzybowski et al.), Wydawnictwo Zysk i S-ka, Poznań.

Lovecraft, H. P. (2018), Wyzwanie z innego świata (tłum. Radosław Jarosiński i Mateusz Kopacz), Wydawnictwo IX, Kraków.

Mikulski, J. (2013), „Howard Phillips Lovecraft: autor, dzieło i jego recepcja wydawnicza w Polsce. Zarys problematyki”, Acta Universitatis Wratislaviensis. Studia o Książce i Informacji. 32: 31-43.

Misterek, D. (1998), „Typy przestrzeni w prozie Howarda Philipsa Lovecrafta”, Literatura i Kultura Popularna. 7: 121-130.

Musiał, Ł. (2015), „Lovecraft i jego brat”, Przeglad Polityczny. 132: 70-77. 
Olkusz, K. (2008), „Świat według potwora, czyli gra z toposem «Obcego» w opowiadaniu «Przybysz» Howarda Phillipsa Lovecrafta”, Studia Filologiczne (Racibórz). 2: 185-194.

Petoia, E. (2004), Wampiry $i$ wilkołaki. Źródła, historia, legendy od antyku do wspótczesności (thum. Aneta Pers et al.), TAiWPN Universitas, Kraków.

Pęczak, M. (2016), „Literatura kosmicznego strachu”, Polityka. 31(3070): 80-82.

Płaza, M. (2012), „W przeddzień potwornego zmartwychwstania”, [w:] H. P. Lovecraft, Zgroza w Dunwich i inne przerażające opowieści (tłum. Maciej Płaza), Wydawnictwo Vesper, Poznań, 761-792.

Skwara, M. (2010), „Translatologia a komparatystyka. Serie przekładowe jako problem komparatystyczny”, Rocznik Komparatystyczny. 1: 7-51.

Skwara, M. (2014), „Wyobraźnia badacza - od serii przekładowej do serii recepcyjnej”, Poznańskie Studia Polonistyczne. Seria Literacka. 23(43): 99-117, https://doi.org/10.14746/pspsl.2014.23.6

Szkłowski, W. (1986), „Sztuka jako chwyt” (tłum. Ryszard Łużny), [w:] Stefania Skwarczyńska, red. Teoria badań literackich za granica. Antologia, t. 2, cz. 3, Wydawnictwo Literackie, Kraków, 10-28.

Valls, X. (red.) (2005), El gran libro del miedo, Parramón, Barcelona.

Valls, X. (red.) (2008), Wielka księga strachu (tłum. Ewa Morycińska-Dzius), Wydawnictwo Media Rodzina, Poznań.

Zwoliński, M. (2009), The Peculiar Horror of Howard Philips Lovecraft, [w:] Sławomir Wącior, red. Literary Liaisons. Text - Culture - Society, Wydawnictwo KUL, Lublin, 169-184.

\section{Netografia}

H. P. Lovecraft. Polski serwis, [online] http://www.hplovecraft.pl, 10.01.2019.

Slownik języka polskiego PWN, [online] http://www. sjp.pwn.pl, 10.01.2019.

Stownik Merriam-Webster, [online] http://www.merriam-webster.com, 10.01.2019.

The H. P. Lovecraft Archive, [online] http://www.hplovecraft.com, 10.01.2019.

\section{STRESZCZENIE}

Artykuł omawia mechanizmy translatorskiej recepcji prozy Howarda Phillipsa Lovecrafta w Polsce na przykładzie opowiadania The Outsider. Oryginał tej krótkiej gotyckiej opowieści o tajemniczym samotniku odwiedzającym ludzką społeczność nie ma jednoznacznej wykładni interpretacyjnej - kluczowe pytania o tożsamość bohatera-narratora postawione $\mathrm{w}$ fabule zostają przez amerykańskiego autora celowo pozostawione 
domysłom czytelników. Polskie warianty natomiast - wskutek modyfikowania tekstu w procesie przekładu - w różny sposób konkretyzują i uzupełniają opowiadanie Lovecrafta, zastępując interpretacyjną zagadkę indywidualnymi odczytaniami pięciorga tłumaczy (Grzegorza Iwanciwa, Roberta Lipskiego, Ewy Morycińskiej-Dzius, Mateusza Kopacza i Macieja Płazy), na które wydatny wpływ mają czynniki pozatekstowe: wizja autora oryginału, wiedza o całokształcie jego twórczości, implikowani czytelnicy przekładu czy dominujące w polskim obiegu literackim mody artystyczne.

Slowa kluczowe: modyfikacja translatorska, recepcja, konkretyzacja, adaptacja, weird fiction

\section{Abstract \\ Imperative of Concretization: Translational Shifts and the Models of Reception of Howard Phillips Lovecraft's Prose - The Case Study of The Outsider and its Polish Versions}

The article discusses translational reception of Howard Phillips Lovecraft's prose in Poland on the example of his short story The Outsider. The gothic tale of a mysterious recluse visiting human society, in its original version, has no explicit interpretation due to the fact that the main character's identity is intentionally left by Lovecraft without precise and unambiguous explanation for its readers to determine. Polish versions, however, modified in the process of interlinguistic transfer, are aimed at concretization of the text, and thus solving this interpretational puzzle with different answers given by five translators (Grzegorz Iwanciw, Robert Lipski, Ewa Morycińska-Dzius, Mateusz Kopacz and Maciej Płaza), influenced by a variety of factors: image of the American writer, knowledge of his other literary works, implied readers of the translations and artistic trends popular in Polish literature.

Keywords: translational shift, reception, concretization, adaptation, weird fiction 